Indeed, the experimental results reported by Braude et al. reveal the lack of a scientific basis for the prefix, given that they have established a specific biochemical effect characteristic of human individuality already at the 4- or 8-cell stage, in the expression of its distinctive genes.

I would therefore expect that this example of subjective and arbitrary terminology be carefully excluded from the scientific literature, the considerations of Chargaff in a recent Commentary in Nature being surely of some relevance to this issue ${ }^{3}$.

Department of Chemistry,

A.J. McEvoY

Institute of Physical Chemistry,

EPFL-Ecublens,

CH-1015 Lausanne,

Switzerland

1. Nature 332, 459 (1988).

2. 1st and 2nd Reports of the Voluntary Licensing Authority for Human Fertilisation and Embryology (Medical Research Council, London, 1985 and 1986.)

3. Nature 327, 199 (1987).

\section{PhD theses}

SIR-Lars H. Breimer (Nature 332, 481; 1988) paints too rosy and chauvinistic a picture of the Swedish PhD system, which has some disadvantages. It is true that a Swedish thesis is often based on four or five articles published in journals but this is not a statutory requirement. In fact, the Swedish statutes allow as equally valid alternatives a collection of articles (single or multiauthored) not published in this way as well as a monograph-type, previously unpublished thesis.

Because a thesis in Sweden has been given an ISBN number, printed and distributed before its public defence, it remains registered as $\mathrm{a} \mathrm{PhD}$ thesis in the university library, whether or not it is passed by the examiners' committee. There is no provision in the Swedish system (as there is in the British) for revision and resubmission of a thesis, a major drawback that sometimes amounts to pressure on the examiners to give a borderline candidate the benefit of the doubt rather than fail him/her. And according to the Swedish Universities Statutes, neither the reasons for the acceptance of a thesis nor any dissent in the examiners' committee meeting may be reported in the minutes of the meeting or in any other document (Chapter 8, Article 37, paragraph 5). The majority decision of the committee is final.

The printing and mailing costs for the statutory number of copies are paid by the faculty only up to a certain maximum amount. Local faculty rules may require that $100-150$ copies be made available before the defence. Although the costs are paid in part, the work of addressing, mailing and delivering copies is done largely by the secretarial staff of the department concerned and its cost is not reimbursed. Even if the thesis consists of published journal articles, these must also be supplied in the required number. The system tends to be wasteful of work and material.

The public oral defence is potentially a valuable procedure that should be retained but a candidate is rarely failed once the thesis has reached this stage. Such an event creates newspaper headlines. I can recall only two cases of rejection in Sweden in the past 15 years.

The upshot is that although the Swedish system has many good points, it is in need of some overhaul.

As to the part of Breimer's letter concerning the situation up to about 25 years ago, it is true that there used to be three opponents. One of them was, however, nominated by the candidate himself and confined himself largely to pointing out undotted i's, uncrossed t's, punctuation errors and the like. The third opponent, also nominated by the candidate, was invariably a ceremonial figure, who made witty remarks at the end about the thesis (no real criticism). Even in those days, a thesis could almost never be failed at this stage although one redeeming feature of the old system used to be that the thesis could be given a grade ( 1 to 5 or rather on a letter scale $\mathrm{C}$ to $\mathrm{A}$ ) instead of only passed or failed as in the present system.

D.S. PARASNIS

Department of Applied Geophysics,

Luleå University of Technology,

S-951 87 Luleå,

Sweden

SIR-In "The thesis that won't go away" (Nature 331, 497; 1988), Beverley Halstead puts forward a number of important but contradictory views. As research students, we would support the suggestion that a PhD should be a period of apprenticeship but we do not agree with the idea that the only way to assess the worth of a scientist is by measuring the volume of work published. In order to demonstrate one's competence as a research scientist, is it absolutely necessary to reach a point at which the work is suitable for publication? Indeed, such a requirement could feasibly lead to a situation in which the integrity of the work is sacrificed for prompt and plentiful publication.

In addition, the successful completion of a project is not solely dependent on a student's ability as there is great variation between PhD projects with regard to difficulty, supervision and availability of resources. A student in a well-funded laboratory who is part of a large group may receive greater stimulation and help than a student of equal ability struggling on his or her own in an ill-equipped laboratory. Furthermore, a student who focuses on a single problem with the aim of publishing the data may become a less competent research scientist than one who has been encouraged to take a more holistic view of his or her work. It is already apparent that the pressure to produce a thesis encourages students to consider only those areas within their own field which are of immediate relevance to their project and the pressure to publish inevitably increases the risk of their pursuing their subject narrow-mindedly.

The thesis system is certainly not perfect, but it is still the fairest method of establishing whether or not a student is worthy of a doctorate. We believe there is urgent need for change within this system rather than its replacement with another. Most importantly, an attempt must be made to unify across universities the standards of assessment used by individual examiners.

\section{Anthony P. Hollander} Bubbly Dularay

Department of Pathology,

University of Bristol,

Medical School,

University Walk,

Bristol BS8 1TD, UK

SIR-A. J. Greenfield's letter (Nature 332, $481 ; 1988)$ about the apparent disparity in the remuneration of $\mathrm{PhD}$ students and $\mathrm{PhD}$ research assistants is misleading.

The salient differences, which he omits to mention, may be summarized as follows. The $\mathrm{PhD}$ student is generally a new graduate with few financial responsibilities, and can therefore afford to take a higher degree which will enable him or her to pursue research in any field which takes his or her fancy.

A $\mathrm{PhD}$ research assistantship, however, is preferentially given to someone with a number of years' relevant experience in industry or elsewhere on top of a good first degree, and is therefore likely to be considerably older with many more financial commitments. His salary is being paid by an institution which requires a specific piece of research to be undertaken, and about whose direction the researcher has very little say. $\mathrm{He}$ is therefore being paid to do a job of work, after which he will no doubt be required to produce a report of his findings to his sponsor.

The fact that a revised copy of the report may be submitted as a thesis and offered to the research institution for evaluation is irrelevant. The $\mathrm{PhD}$ is a bonus which is rightfully gained for having satisfied the academic criteria governing such research.

The saving grace of this alarming debate is that, given the historic traditions of the better universities, it will be a very long time indeed before any change is seen in the present, and eminently satisfactory, system.

Corner Cottage,

S. J. SHEPHERD

St John, Torpoint,

Cornwall PL11 3AW, UK 